\title{
Medicine an evolving profession
}

\author{
Moyez Jiwa
}

Editor, AMJ

REVIEW

Please cite this paper as: Jiwa M. Medicine an evolving profession. AMJ 2013, 6, 4, 196-202. http://doi.org/10.21767/AMJ.2013.1683

Corresponding Author:

Moyez Jiwa.

Email: Editor@amj.net.au

Abstract

The number of medical practitioners in the developed world has increased but in relative terms their incomes have decreased. Published comments suggest that some doctors are dissatisfied with what they earn. However doctors are still perceived as having a high status in society. Publicly available data suggests that doctors chose to live and work in affluent suburbs where arguably the need for their skills is less than that in neighbouring deprived areas. The gender balance in medicine is also changing with more women entering the workforce and a greater acceptance of parttime working arrangements. In some countries doctors have relinquished the responsibility for emergency out of hours care in general practice and personal continuity of care is no longer on offer. The profession is also challenged by policy makers' enthusiasm for guidelines while the focus on multidisciplinary teamwork makes it more likely that patients will routinely be able to consult professionals other than medical practitioners. At the same time the internet has changed patient expectations so that health care providers will be expected to deploy information technology to satisfy patients. Medicine still has a great deal to offer. Information may be readily available on the internet, but it is not an independently sufficient, prerequisite for people to contend with the physical and psychological distress associated with disease and disability. We need to understand and promote the crucial role doctors play in society at a time of tremendous change in the attitudes to, and within, the profession.

Key words: Doctors, profession, income, working hours
Everyone knows a doctor

Most people know a doctor or a medical student personally. Doctors are relatives, neighbours, friends or colleagues. There are more doctors than at any time in the past. ${ }^{1}$ Like the royal family we now know more about doctors, their private and professional lives than we ever did. In the 1960s we only ever saw them in a white coat or at a clinic, living in an upmarket or exclusive, sometimes gated neighbourhood. We now rub shoulders with them at the supermarket, in the gym, on holiday and at the cinema or football match. Not only are they more visible but they are not just seen in exclusive or exclusive locations. We also see them eating fast food, sitting in the cheap seats, going on package holidays and shopping in bargain basement shops. In fact, relatively speaking, doctors' incomes have been overtaken by other professional groups. That means that the Ferrari in the car park is more likely to belong to the estate agent than to a doctor. A Rolex is more likely to be worn by a banker than a hospital specialist. A recent article in the New York Times described law and medicine as the 'FallingDown professions'. ${ }^{2}$ According to the author Alex Williams:

'In a culture that prizes risk and outsize reward - where professional heroes are college dropouts with billion-dollar Web sites - some doctors and lawyers feel they have slipped a notch in social status, drifting toward the safe-andstaid realm of dentists and accountants. It's not just because the professions have changed, but also because the standards of what makes a prestigious career have changed. 2

\section{Why medicine?}

The reasons why young people may want a career in medicine is also discussed on the World Wide Web. On a Malaysian blog site one student discusses why some people say they want to dedicate their lives to caring for the sick. ${ }^{3}$ Despite the idea of serving the needy the authors speaks of not wanting a government scholarship for fear of being committed to work in a designated area of medical need. In the authors view such areas tend to be in deprived communities with fewer amenities. Government service is regarded as onerous, with long periods on call. The author highlights the desire for prestige and financial reward and at 
the same time regards the suggestion that students are driven to medicine by parental pressure as hypocrisy.

There are of course more 'politically correct' reasons to enter medical school. Some websites suggest that if such reasons are regurgitated at a pre-entrance interview a prospective student is more likely to be offered a place at their preferred medical school ${ }^{4}$

\section{Practice location}

The distribution of professionals by locality is documented on the Internet. Table 1 juxtaposes the number of assaults per 1000 residents reported by the police to the number of general practitioners listed on a website commonly used to identify doctors in an area and the population of some suburbs in Perth, Western Australia. Included on the table are the median house prices in the relevant suburbs at that time. Comparing the beachside suburb of Hillarys with the less affluent suburb of Wanneroo there are substantially more doctors working and perhaps living in the former location.

Figure 1: Hillarys Western Australia

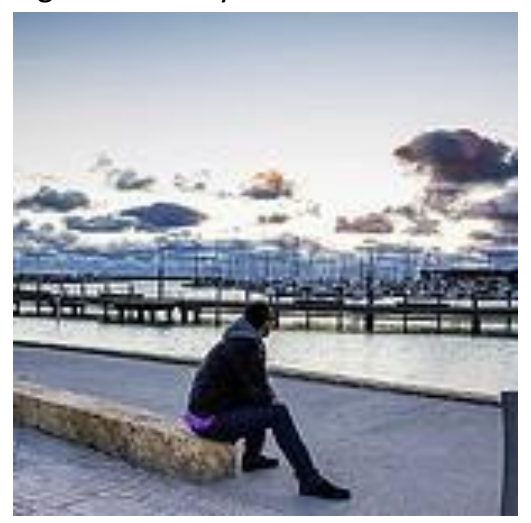

Photo by Daniel E Lee

(http://www.flickr.com/photos/dlee13/)

Some parts of town are clearly more popular than others. Doctors prefer to live and practice in the leafy suburbs. This is despite the fact that disease and disability are related to poverty and there is a greater need for doctors in deprived areas. This was noted in a review of doctor distribution in Perth with 36 suburbs listed as areas of unmet need for doctors. Western Australian Health Department figures suggest that since the start of 2010, 11 suburbs joined the list of areas missing out on general medical services. Five are in the less affluent Rockingham region - Baldivis, Warnbro, Golden Bay, Secret Harbour and Port Kennedy. ${ }^{5}$ This is another example of Tudor Hart's inverse care law. ${ }^{6}$ The observation that provision of health services is often least satisfactory in areas where need is the greatest.
Table 1: Distribution of GPs in selected suburbs of Perth, Western Australia. In descending size of population

$\begin{array}{lllll}\text { Suburb } & \begin{array}{l}\text { No of } \\ \text { Doctors } \\ 7\end{array} & \begin{array}{l}\text { Assaults } \\ \text { per } 1000 \\ \text { residents }\end{array} & \begin{array}{l}\text { Population } \\ \text { of suburb }\end{array} & \begin{array}{l}\text { Median } \\ \text { House } \\ \text { price as } \\ \text { 000 dollars }\end{array} \\ \text { Armadale } & 21 & 16 & 20101 & 275 \\ \text { Rockingham } & 37 & 28 & 11463 & 365 \\ \text { Nedlands } & 35 & 3 & 10973 & 1500 \\ \text { Hillarys } & 36 & 10 & 9430 & 740 \\ \text { Wanneroo } & 20 & 14 & 9086 & 380 \\ \text { Maddington } & 13 & 19 & 9006 & 312 \\ \text { Bull Creek } & 18 & 3 & 7975 & 575 \\ \text { Claremont } & 31 & 16 & 7039 & 1300 \\ \text { Floreat } & 33 & 3 & 7029 & 1050 \\ \text { Carine } & 25 & 3 & 6834 & 707 \\ \text { Cottesloe } & 19 & 14 & 6803 & 1800 \\ \text { Dalkeith } & 7 & 1 & 4286 & 2480\end{array}$

\section{Income}

Perhaps the worst kept secret about doctors $s$ their income. It is possible to go online and confirm the salaries for the average specialist working in Australia as ranging from $\$ 200-400,000$ per year. ${ }^{11}$ General practitioners earn a little less ranging more like 100-250,000. ${ }^{12}$ Relative to other professions these figures, though reasonable, are declining. In the United States the average physician net income declined by about $7 \%$, in inflation-adjusted terms, between 1995 and 2003, while other professionals saw about a 7\% increase during this period, according to a national study from the Center for Studying Health System Change. Primary care physicians experienced a $10.2 \%$ decline in real income. Surgeons experienced an $8.2 \%$ decline, while income levels for medical specialists remained unchanged. ${ }^{13}$

Associates at major New York firms often start at $\$ 150,000$ to $\$ 180,000$, according to Salary.com, a company that tracks income statistics. ${ }^{14}$ Partners at the country's biggest 100 firms took home an average of $\$ 1.2$ million in 2006, according to American Lawyer. Hardly small sums, but for many senior investment bankers, bonuses and salaries in 2010 averaged $\$ 2.25$ million to $\$ 2.75$ million, according to Options Group, an executive search and consulting firm. 
Doctors' incomes vary widely, a typical physician might earn $\$ 150,00$ to $\$ 300,000$, according to Salary.com data. A surgeon might make $\$ 250,000$ to $\$ 400,000$; private clinic surgeons can earn $\$ 750,000$ a year, and very rarely over a million dollars. Here's what some doctors in the UK are reported to have said about their salaries in $2009 .{ }^{15}$

Age: 25

Job: Foundation year 1 trainee

NHS earnings: $£ 21,190$ to $£ 31,785$

Total income: $£ 26,839$

Hourly rate: $£ 10 \mathrm{GBP}$

"I think we do feel our pay is a bit low, especially when we look at what friends our age are earning. When I tell people my basic salary, they're shocked because they think doctors are loaded. Yet there are more and more medical students coming through and getting into serious debt."

\section{Age: 29}

Job: Specialty trainee 3 in gastroenterology

NHS earnings: $£ 45,000$

Total income: About $£ 47,000$ (including extra shifts)

Hourly rate: About $£ 18$

She would like to earn more. "Realistically we should be paid a bit more. I actually earned more as a senior house officer than I do now," she says.

Age: 53

Job: Orthopaedic and trauma surgeon

NHS earnings: $€ 79,000$

Total income: $£ 81,000$ (including private work)

Hourly rate: About $£ 17.90$

He admits he'd like to earn more. "We earn the same money as a consultant starting out and very rapidly that moves apart. I would say that as a senior hospital clinician my pay should probably be $10-15 \%$ higher than it is at present."

Age: 44

Job: Consultant paediatrician

NHS earnings: $£ 100,000$

Total income: $£ 100,000$

Hourly rate: About $£ 44$

"Personally, I think I'm worth the money because of the level of responsibility, the amount of training I've done, and my experience."

Age: 49

Job: Full-time GP partner

NHS earnings: $£ 110,000$

Total income: $£ 117,000$ (including private consultations)
Hourly rate: About $£ 45$ an hour

"Yes, it's a lot of money for one person to earn, but if you look at my practice's NHS income then you're talking about f24 every time someone comes to see us," he says. "If you compare that to going to see a dentist or a vet then that's fantastic value."

Age: 60

Job: Consultant physician

NHS earnings: $£ 175,000$

Total income: About $£ 180,500$ (including medico-legal work, private practice, and book royalties)

Hourly rate: $£ 48$

"I earn much more than most people in most sectors, but then I have three degrees and a doctorate and am an FRCP [fellow of the Royal College of Physicians] but that's not unusual for a consultant at a large teaching hospital," he says. "We have more letters after our names than most bankers and lawyers, and that may be one reason we're worth the money."

\section{Working hours}

A career in medicine was once thought to require a life-long commitment without periods of parental leave, time to be home for dinner or to read the kids a bedtime story. However there have been significant changes in attitudes over the past few years. A clear indication of this change occurred in the UK more with a whimper rather than the cataclysmic bang that was predicted by some. Once an example of a truly encompassing health service, serving people 24/7 regardless of their ability to pay, GPs in Britain's NHS relinquished responsibility for 24 hour care of their patients from 2005. ${ }^{16}$ At the same time GPs had seen their pay increase under the terms of the contract introduced by the labour government that also offered the scope to opt out of responsibility for emergency out of hours care. The current government is hoping GPs will be more available to serve patients after office hours, however there is data from elsewhere in the world that where reform has removed the responsibility for out of hours work that such work is no longer appealing to practitioners and in some cases such reform has been potentially detrimental to patients. ${ }^{17,18}$

A once sacred cow the home visit has also shown marked reduction in the UK. ${ }^{19}$ No longer do many doctors feel able to afford the opportunity cost of visiting patients at home in an increasingly busy day. The argument that home visits offered a considerable insight into the patient's circumstances and therefore their help seeking behaviour appears to have less currency. ${ }^{20}$ At the same time general practice has become a more popular choice among medical 
graduates in the UK perhaps because it is seen as offering a superior work-life balance. Both men and women are attracted to opportunities to work reduced hours and to be employed as opposed to owning the business. ${ }^{21}$

GPs in Britain are increasingly working part-time or as salaried doctors. Recent surveys confirm that those most likely to be salaried are GPs seeking greater career flexibility (for example, part-time working), and who wish to be free from the roles and responsibilities of having a financial stake in the business: including some women of childbearing age, newly qualified GPs, and GPs nearing retirement. ${ }^{22}$ For such doctors' families their income may be a second income. Job sharing is no longer frowned upon as many specialities, including and especially general practice.

Once the preserve of males, there are now record numbers of female doctors. ${ }^{23,24}$ The proportion of female doctors in some parts of the world has increased to $37.6 \%$ and female medical practitioners choose to work fewer hours than males. ${ }^{25}$ Some commentators have spoken of the 'sexual division' of labour noting that female practitioners are more often consulted by the core demographic in general practice namely women and young children. ${ }^{26}$

\section{Continuity of care}

Interpersonal continuity, built on repeated (but not necessarily exclusive) contacts, is important in building trust and respect. Such continuity of care, once the hall mark of the generalists is now under threat. Even in Britain, patients are now able to register with more than one practice and in most cases practices are group partnerships so that patients are likely to consult more than one doctor. ${ }^{27}$ The surprising thing is that patients do not mind it so much. Respondents to one survey were asked to indicate their preference to wait longer to see a familiar medical practitioner who was well informed about their case when they had a problem causing uncertainty or needed a routine check-up. They preferred quick access for likely minor 'low impact' symptoms. ${ }^{28}$ In countries where there is limited continuity of care, even inasmuch as there are no common medical records this might lead to the phenomenon of 'Doctor shopping', the term coined in Australia to describe the behaviour of a person who has, in a three-month period, been supplied prescription drugs by six or more different prescribers, or has been prescribed a total of 25 target pharmaceutical benefits or 50 or more pharmaceutical benefits in total. ${ }^{29}$

From birth to death was the catch cry of UK general practice, but in the 21st century it is likely that in that country an increasingly mobile population will consult more than one doctor per episode of illness much less one doctor in a life time. For a host of reasons, some of which are related to the risk of litigation and inadequate training, GPs do not routinely attend home births. ${ }^{30}$ Fewer doctors visit patients at home and few doctors are involved in the care of the dying patient $24 / 7$ other than in hospitals. ${ }^{31}$ When asked where people would prefer to die most people say at home. The reality is, despite this patient preference, the majority of people are still destined to die in a hospital. ${ }^{32}$

Meanwhile the attitudes of funding bodies have also changed. Once prepared to promote the concept of the generalist, able to somehow cater for the needs of people throughout life and through whatever illness, the funders have focused much more on efficiency and demonstrating 'value for money'. ${ }^{33}$ It is difficult to see how one can measure the comfort that is offered in having the medicine man call to demonstrate compassion for your dying grandmother, it is easier to count how often the doctors check her blood pressure and make other measurements when she is brought to the clinic. The UK Quality Improvement Framework was introduced to improve measurable outcomes in primary care, it particularly incentivised the collection of data as a measure of service to the patient. The possible impact of such incentives on the experience for the patient is discussed elsewhere but there is a risk that doctors may be distracted by the need to collect and document measured data sometimes even before the patient is able to say why they think they need to see a doctor on that occasion. ${ }^{34,35}$

\section{Algorithm medicine}

Another trend is the fashion for what may be called 'algorithm medicine'. ${ }^{36}$ In the light of the consequences of a variety of unfortunate medical misadventures doctors are now encouraged to follow 'protocols' for the management of even the simplest problem. This trend has not quite become fully established yet but the art of medicine is being influenced by what passes as science. The UK NHS cancer referral guidelines epitomises a significant national experiment in the beginnings of this trend. The government introduced a set of guidelines to direct the rationing of access to specialists under the assumption that it is possible to recognise cancer symptoms among patients who present to doctors in general practice. The second premise was that such patients are not referred in time because doctors fail to recognise these symptoms. In addition the government guaranteed people access to a specialist within two weeks if they were referred by GPs under suspicion of cancer. ${ }^{37}$ However the predictive value of symptoms presented in general practice is low. ${ }^{38}$ The yield of treatable cancers under the two-week wait initiative was disappointing. ${ }^{39}$ 
Nonetheless policy makers have continued to introduce more 'evidence based' guidelines in the hope improving outcomes for patients. ${ }^{40}$

Teamwork is now the mantra in health services. In hospital settings it is an established way of working. However doctors, such as those in general practice in Australia who have until recently worked in isolation are not formally incentivised to work in teams. ${ }^{41}$ In the UK teamwork is more established and promoted through funding. ${ }^{42}$ In the years ahead in some parts of the world there will be a need for greater integration of health professionals and therefore it is more likely that patients will consult a nurse or an allied health professional where until recently they had consulted a doctor.

\section{Service and information}

Allied to these developments are data that suggest that, through the internet, people have become better informed but have also had their expectations raised. The major driving forces that are pushing the internet into health and health care are strong and unstoppable; they ensure that the internet will be integrated into and shape health care. ${ }^{43}$ The key points are:

1. Consumers have almost unfettered access to information via the internet. They have come to expect high levels of choice, control, customer service, interaction with service providers, and access to information.

2. Consumers' expectations are shaped by their experience of using the electronic technology in other areas of their lives including shopping. Health care providers will be expected to deploy the internet to meet patients' expectations.

3. Access to the internet is relatively inexpensive. The internet is easy to use, provides a diversity of health care information, and opens its users to a global network of people with common interests.

4. Competitive health care organisations are now using the internet as a channel to promote their services.

\section{Conclusion}

We have never had as many doctors as we have now per head of population in the developed world. The number of doctors per capita increased $2 \%$ per year on average across OECD countries between 1990 and 2007. ${ }^{1}$ We know, or can easily find out, what doctors earn in our locality, where they live, their likes, dislikes, their fears and failures. Facebook and other social networking sites include dozens of forums dedicated to doctors or medical students. Anyone can join and become privy to the, ideas, concerns and expectations of individuals who continue to be highly respected.

Doctors serve a fundamental human need. The need for hope through pain and distress. Medicine has a great deal to offer. However doctors can now choose whether they wish to serve as 'father figures' or 'plumbers'. ${ }^{44}$ It is now possible for doctors to work relatively shorter hours, within defined parameters but also to broadly embrace what a career in medicine still has to offer. To accept the challenge of serving in a world where information is freely available and choices are legion. A glimpse into a virtual, computergenerated future still leaves patients needing to discuss their options with another human being. Most patient's decisions are not determined on facts only. ${ }^{45}$ Those who choose a career in medicine and those who fund that service must be clear how doctors serve society. ${ }^{46}$

\section{References}

1. OECD Health Data 2009. [Online]. Available from http://www.oecd.org/document/54/0,3343,en_26 49_201185_43220022_1_1_1_1,00.html. Accessed 23 Feb 2013.

2. Williams A. The falling-down professions. New York Times. [Online]. Jan 6, 2008. Available from http://www.nytimes.com/2008/01/06/fashion/06p rofessions.html?_r=1\&ex=1215406800\&en=95d14 468fd97b411\&ei=5087\&excamp=NYT-E-I-NYT-EAT-0108-L1\&WT.mc_ev=click\&WT.mc_id=\%20NYT-EI-NYT-E-AT-0108-L1. Accessed Nov 23 Feb 2013.

3. Jalapeno. Why do you want to become a doctor? [Online]. Available from http://silencecankill.blogspot.com/2008/07/whydo-you-want-to-become-doctor.html. Accessed 26 Feb 2013.

4. PreMed e-Library. Lesson One: The Why Doctor? [Online]. Theme Available from: http://www.bestpremed.com/essayedge/lesson2.h tm. Accessed 26 Feb 2013.

5. Government of Western Australia. List of Current Determinations for Area of Need in Western Australia In accordance with the Health Practitioner Regulation National Law (WA) Act 2010 67(5) [Online]. Available from http://www.overseasdoctors.health.wa.gov.au/doc s/UAN_Database.pdf /. Accessed 26 Feb 2013. 
6. Tudor Hart J. The Inverse Care law. The Lancet, 1971; 297: 405-412.

7. Perth Medical Practitioners. Homepage on the internet. [Online]. Available From: http://www.doctors-4u.com/perth/alpha_ab.htm. Accessed 26 Feb 2013.

8. Real Estate Institute of Western Australia. Perth suburbs sorted by population. [Online]. http://www.viacorp.com/perth-suburbs-bypopulation.html. Accessed 26 Feb 2013.

9. Real Estate Institute of Western Australia. [Online]. Perth suburbs sorted by assaults. Available from: http://www.viacorp.com/perth-suburbs-byassaults.html._Accessed 26 Feb 2013.

10. Real Estate Institute of Western Australia. House prices in Perth for each suburb. [Online]. Available From: http://www.viacorp.com/perth-suburbslisted-by-median-price.html. Accessed 26 Feb 2013.

11. International Medical Recruitment. Salaries in Australia. [Online]. http://www.imrmedical.com/australiasalaries.htm Accessed 26 Feb 2013.

12. Wavelength International. Medical Work in Australia FAQs. [Online]. Available From: http://www. wave.com.au/faq. aspx?id=45.

Accessed 26 Feb 2013.

13. Physician Salaries Declined over Last Decade Oncology Times: 10 August 2006 - Volume 28 Issue $\quad 15$ - $\quad p \quad 30$ doi: 10.1097/01.СОТ.0000293390.79865.16.

14. Salary.com. Homepage on the internet. [Online]. Available from http://www.salary.com/. Accessed Nov 2010.

15. Stephenson J. What doctors earn. BMJ Careers. 2/09/2009. [Online]. Available from http://careers.bmj.com/careers/advice/viewarticle.html?id=20000354. Accessed 26 Feb 2013)

16. Roland M. Linking physician pay to quality of care: a major experiment in the UK. N Engl J Med. 2004 Sep 30;351(14):1448-54.

17. van Uden CJT, Giesen MD, Job FM,Metsemakers MD, Grol R. Development of out of hours primary care by general practitioners (GPs) in the
Netherlands: From small-call rotations to largescale GP cooperatives. International Family Medicine, 2006; 38: 565-569. Retrieved from http://www.stfm.org/fmhub/fm2006/September/C aro565.pdf

18. Gallagher N, Macfarlane A, Murphy AW, Freeman GK, Glynn LG, Bradley, CP. Service Users' and Caregivers' Perspectives on Continuity of Care in Out-of-Hours Primary Care. Qual Health Res. 2013 Mar;23(3):407-21.

19. The Information Centre. 2006/07 UK General Practice Workload Survey. [Online]. Available from http://www.dhsspsni.gov.uk/gp_workload_survey_ 2006_07.pdf._Accessed 26 Feb 2013.

20. Pereira Gray D J. Feeling at home. James Mackenzie Lecture. Journal of the Royal College of General Practitioners 1978; 28: 6-16.

21. Jones L, Fisher T. Workforce trends in general practice in the UK: results from a longitudinal study of doctors' careers. Br J Gen Pract. 2006; 56:134-6.

22. Ding A, Hann M, Sibbald B. Profile of English salaried GPs: labour mobility and practice performance. Br J Gen Pract. $2008 ; 58: 20$

23. Dacre J. Are there too many female medical graduates? No. BMJ. 2008; 336:749.

24. McKinstry B Are there too many female medical graduates? Yes. BMJ. 2008; 5; 336: 748

25. AlHW., Medical workforce 2011. National health workforce series no. 3. Cat. no. HWL 49. Canberra:. Canberra, 2013: p. 69.

26. Brooks F. Women in general practice: Responding to the sexual division of labour? Soc Sci Med. 1998; 47: 181-193.

27. Freeman GK, Olesen F, Hjortdahl P. Continuity of care: an essential element of modern general practice? Fam Pract. 2003 Dec;20(6):623-7.

28. Turner D, Tarrant C, Windridge K, Bryan S, Boulton M, Freeman G, Baker R.Do patients value continuity of care in general practice? An investigation using stated preference discrete 
choice experiments. J Health Serv Res Policy. 2007 Jul;12(3):132-7.

29. Kamien M. "Doctor shoppers": at risk by any other name. Med J Aust. 2004 Mar 1;180(5):204-5.

30. Wiegers T.A. General practitioners and their role in maternity care. Health Policy. 2003Oct;66(1):51-9.

31. Burt J, Barclay S, Marshall N, Shipman C, Stimson A, Young J. Continuity within primary palliative care: an audit of general practice out-of-hours cooperatives. J Public Health (Oxf). 2004 Sep;26(3):275-6.

32. Gomes B, Calanzani N, Higginson IJ. Reversal of the British trends in place of death: Time series analysis 2004-2010. Palliat Med. 2012 Mar;26(2):102-7.

33. Mangin D, Toop L. The Quality and Outcomes Framework: what have you done to yourselves? $\mathrm{Br}$ J Gen Pract. 2007 Jun;57(539):435-7.

34. Toop LJ, Mangin D Quality and outcomes framework. Evidence of net benefit is lacking. BMJ. 2007;335:1170.

35. Jiwa M. The business of doctoring. Australas Med J. AMJ 2012,5, 6, 329-333.

36. Woolf SH. Practice Guidelines: A New Reality in Medicine. Arch Intern Med. 1990 Sep;150(9):18118.

37. National Institute of Clinical Excellence. NICE guideline-referral for suspected cancer. June 2005. [Online]. Available From www.nice.org.uk/CG027._Accessed 26 Feb 2013.

38. Summerton N. Making a diagnosis in primary care: symptoms and context. $\mathrm{Br} J$ Gen Pract. 2004 Aug;54(505):570-1.

39. Jiwa M, Saunders C. Fast track referral for cancer BMJ 2007;335:267 doi:10.1136/bmj.39293.453090.AD

40. Keffer JH. Guidelines and Algorithms: Perceptions of Why and When They Are Successful and How to Improve Them. Clin Chem. 2001 Aug;47(8):156372.
41. Jiwa M, Saunders CM, Thompson SC, Rosenwax LK, Sargant S, Khong EL, Halkett GK, Sutherland G, Ee HC, Packer TL, Merriman G, Arnet HR. Timely cancer diagnosis and management as a chronic condition: opportunities for primary care. Med J Aust. 2008;189:78-82.

42. BMJ Group. Chris Ham on General practice in Australia. 2010. [Online]. Available from http://blogs.bmj.com/bmj/2010/11/09/chris-hamon-general-practice-in-australia/.

43. Mittman R, Cian M. The Future of the Internet in Health Care. 1999. The California HealthCare Foundation. [Online]. Available from: http://www.chcf.org/ /media/MEDIA\%20LIBRARY \%20Files/PDF/F/PDF\%20forecast.pdf._Accessed 26 Feb 2013.

44. McCormick J. Father figure or plumber. Croom Helm: London. 1979.

45. Levinson W, Kao A, Kuby A, Thisted RA. Not all patients want to participate in decision making. A national study of public preferences. J Gen Intern Med. 2005 Jun;20(6):531-5.

46. Jiwa B. What Business are you in? [Online]. Available from: thestoryoftelling.com/whatbusiness-are-you-in/. Accessed 26 Feb 2013.

\section{PEER REVIEW}

Not commissioned. Externally peer reviewed.

\section{CONFLICTS OF INTEREST}

The author declares that he has no competing interests 